\title{
The analysis of the technological and professional danger factors specific to the works of exploitation of useful rocks from quarries, which can generate risk of accident and / or technological breakdown
}

\author{
Attila Kovacs $^{1 *}$, Sorin Bordoș ${ }^{1}$, Bogdan Garaliu-Buşoi ${ }^{1}$, Claudia Miron ${ }^{1}$, and Sorina \\ Stănilă \\ ${ }^{1}$ National Institute for Research and Development in Mine Safety and Protection to Explosion - \\ INSEMEX Petroşani, 32-34 G-ral Vasile Milea St., 332047 - Petroşani, Hunedoara County, Romania \\ ${ }^{2}$ University of Petrosani, str. Universitatii 20, Petrosani, Romania.
}

\begin{abstract}
The exploitation of ore deposits or useful rocks, surface operations, implies the application of rigorous technologies regarding the configuration of the operating steps, the safety berms and the slopes, as well as the access ways to working front. The required measures to carry out drilling, shooting and evacuation activities involve both issues related to technological security and safety and health at work for the personnel involved in these activities, mining establishments being required to draw up appropriate instructions for the situation on the ground, covering both technological and SSH issues. In some situations, accidents or technological failures have occurred due to the failure of fully implement these provisions which, sometimes, have also resulted in human casualties. The paper aims at presenting 2 case studies to which INCD - INSEMEX Petrosani carried out technical and scientific expertise for the produced events.
\end{abstract}

\section{Introduction}

Any operation with explosives for civilian use involves risks from the moment of entering the manufacturing, transporting, storage, loading and performing of the shooting. Given that explosives are dangerous goods, they can affect both the personnel directly involved in their use and other people not in the security zone. Serious effects on humans as a result of explosive charges are due either to explosion pressure, throwing of dither material, or to the stability of structures after shooting such as: slopes, operating steps, or building demolition work with explosives [1].

The paper briefly presents two case studies with victims, based on technical and scientific expertise carried out by INCD-INSEMEX at the request of the authorities. In both

\footnotetext{
Corresponding author: attila.kovacs@insemex.ro
} 
accidents, the victims were people who did not directly participate in the blasting activities but their presence in the work area that was affected by the effects led to these accidents.

\section{Case studies}

\subsection{Technical expertise of the event at the stone quarry "Dealul lui Tefic"}

\subsubsection{Description of the accident place}

The objective of technical expertise was to determine the causes that generated the occurrence of the 14.10.2011 event at the stone quarry " DEALUL LUI TEFIC" [2].

\subsubsection{Description of the geometric elements of the steps of the stone quarry "Dealul lui Tefic" Issacea}

The dimensions of the geometric elements of the steps in the open quarry, i.e. the height of the steps, the width of the berms and the slope angle, were calculated and adopted in order to approve the technology according to:

- the geo-morphological structure of the rock-mass in which the step is formed;

- the physical-mechanical characteristics of the rocks in the step;

- working technology related to the exploitation method;

- functional parameters of the equipment used for the execution of the technological operations.

The $15 \mathrm{~m}$ step height adopted with the applied technology according to the exploitation frame method, was correctly set.

Analyzing the field evidences, it is confirmed that the loading and transport activity was carried out safely.

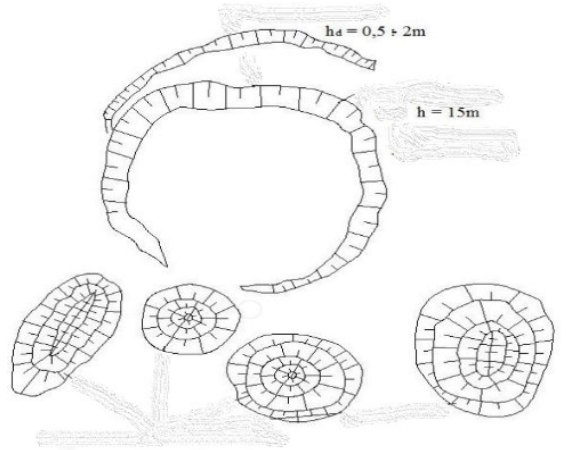

Fig. 1. Dealul lui Tefic Quarry, Isaccea, Tulcea.

By adopting the long-term exploitation method in Dealul lui Tefic quarry, the following main requirements are ensured: full occupational safety, high economic efficiency, minimum reserve losses, field and surface protection, and environmental protection.

Bore drilling and blasting works highlight the following specific parameters:

- height of the step $12-15 \mathrm{~m}$, the variations being generated by the land unevenness from the ground;

- $3.5 \mathrm{~m}$ burden at a slope angle of $75-80^{\circ}$;

- the length of the bore holes in diameter of $102 \mathrm{~mm}$, is 14 or $17 \mathrm{~m}$ depending on the height of the tread, achieving a depth of $2 \mathrm{~m}$; 
- the distance between the holes on the same row is $3 \div 4 \mathrm{~m}$ and the distance between the rows $2.6 \div 3 \mathrm{~m}$.

- number of blasting holes per cycle are 23 , of which 12 on the first row and 11 on the second row;

- initiating the explosive charge through the NONEL non-electric system, with the use of millisecond detonators.

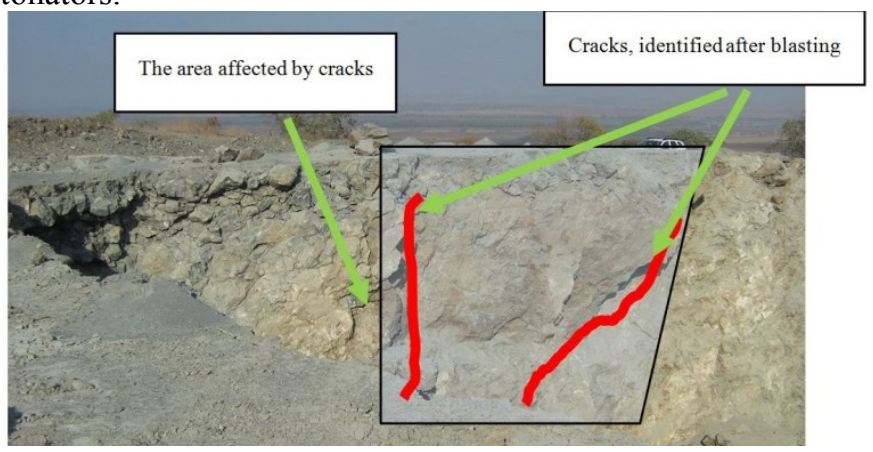

Fig. 2. Geological structure of the slope.

Thus, the burden, the distance between the holes in the same row and the rows have the values specified in the frame method. The explosive charge used to fire the blasting holes consists of 2 FAREX busters of $450 \mathrm{~g}$, with a base and a middle initiation, in the vecinity of the buster being 3 LAMBREX cartridges $\$ 65 \mathrm{~mm} \times 3,125 \mathrm{~kg}$ at the base, respectively 2 LAMBREX cartridges of the same dimensions at middle, as an initiating explosive (fig.3). The explosive in the column is represented by AUSTINITE (ANFO) weighing $70 \mathrm{~kg}$, the length of the load being $14 \mathrm{~m}$ out of the total of $17 \mathrm{~m}$ - the length of the borehole, the loading rate of the bore being $75 \%$ of the height of the step, the amount of explosive per meter of hole the probe being between $4.7-6 \mathrm{~kg} / \mathrm{m}$, the average value being $5.13 \mathrm{~kg} / \mathrm{m}$.

On 14.10.2011, the amount of explosive was $5.25 \mathrm{~kg} / \mathrm{m}$ of bore hole, the amount of explosive per hole - base load - was $70 \mathrm{~kg}$.

Used materials:

- 2 pcs. Booster $450 \mathrm{~g}$;

- 5 pcs. Lambrex 65x3,125 kg;

- $70 \mathrm{~kg}$ Austinite;

- Stemming $3 \mathrm{~m}$.

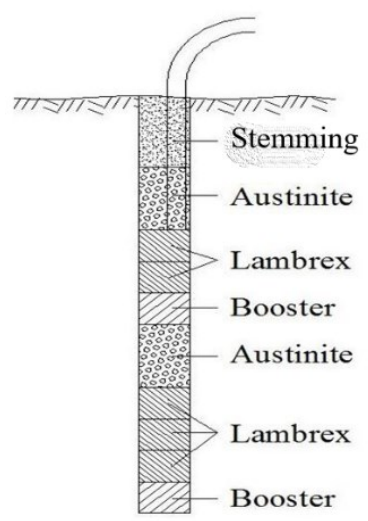

Fig. 3. Loading of the bore hole. 


\subsubsection{The consequences of the event}

Event occurred on October 14, 2011, at the work point Stone quarry " Dealul lui Tefic", Isaccea, had the following consequences [3,4,5]:

- Serious bodily injury of the victim of the S.G. who suffered injuries requiring healing, medical care of 70-80 days, which by their gravity endangered his life and which resulted in permanent physical infirmity due to his being hit by the resulted material at the quarry front blasting operation;

- Mild bodily injury in the head area of the second victim B.G. due to the same causes that did not require hospitalization or special medical care;

- Damage of some equipment in the area where the throwing effect was manifested by the material resulted during the blasting operation;

- Spreading of the material dredged after the blasting operation outside the security zone established by the technical documentation, $300 \mathrm{~m}$ from where the blasting took place.

\subsubsection{The throw effects}

Due to the detonation of an explosive charge, besides the desired effect of dislocation of the material, unwanted effects (material displacement at large distances, airborne shock and eventual seismic effects) can occur, that can affect neighboring objectives.

By analogy with the results of works on the properties of explosive substances, it is shown that it is quite difficult to calculate the energy of rock fragments produced by a detonation $[6,7,8,9]$.

After the geomorphological analysis, tectonic accidents, cracks/fractures, correlation of the hourly data and the location of the blasting works and the event occurs, it is retained as a cause for the occurrence of the event "Fly rocks after the blasting operation due to the presence of previously unidentified cracks/fractures in the front area during drilling and loading of the bore holes".

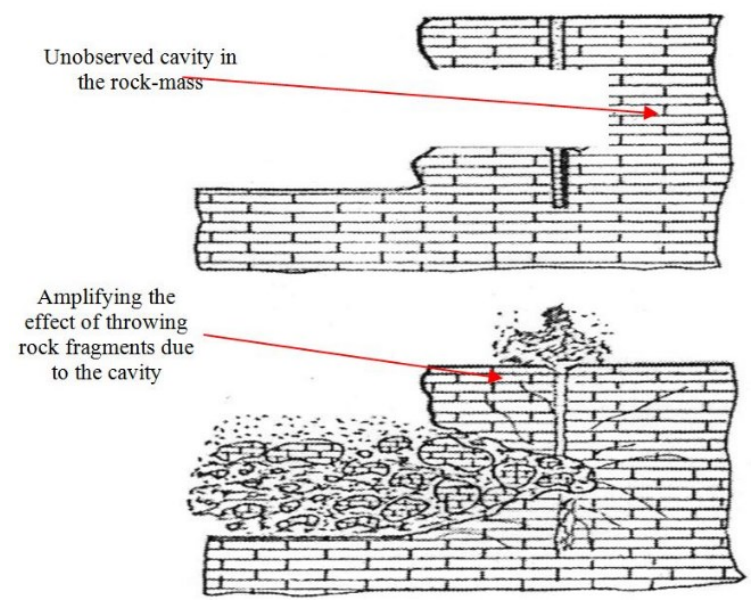

Fig. 4. The throw effect amplification.

The presence of such geological anomalies can lead to overloading the front and modifying the projected parameters (significant decrease of burden) which can result, after the shot, in a displacement effect of the blasted material to considerably larger distances than those established as safety distances for protection people and goods. 
From the data recorded on the file on which the technical expertise was made, there are no indications that there were underground cavities in the front area, which is also supported by those reported by the staff that carried out and coordinated the blasting.

Also, explosive consumption declared and recorded for this work did not give any clues to support the overloading of certain holes due to such gaps in the rock-mass.

\subsubsection{Influence factors}

Amplification of the off-site throw effect due to the use of the shooting technology described in the frame method, in the absence of identification of the two major cracks revealed after the occurrence of the event $[10,11,12,13,14]$.

Withdrawal of personnel was carried out at the minimum safety distance from the shooting front, specified in "Blasting order no. BEN-21.11/14.10.2011" safety and Instructions for the use of personal protective equipment and covering in the case of surface blasting, but it was done in the direction of the front, inadvertently, unprotected by the effects of the detonation.

\subsection{Technical expertise of the event at the quarry "Pârâul Cailor"}

\subsubsection{Description of the event place}

The dolomitic deposit "Pârâul Cailor" is situated on the Fundu Moldovei town area, in the county of Suceava.

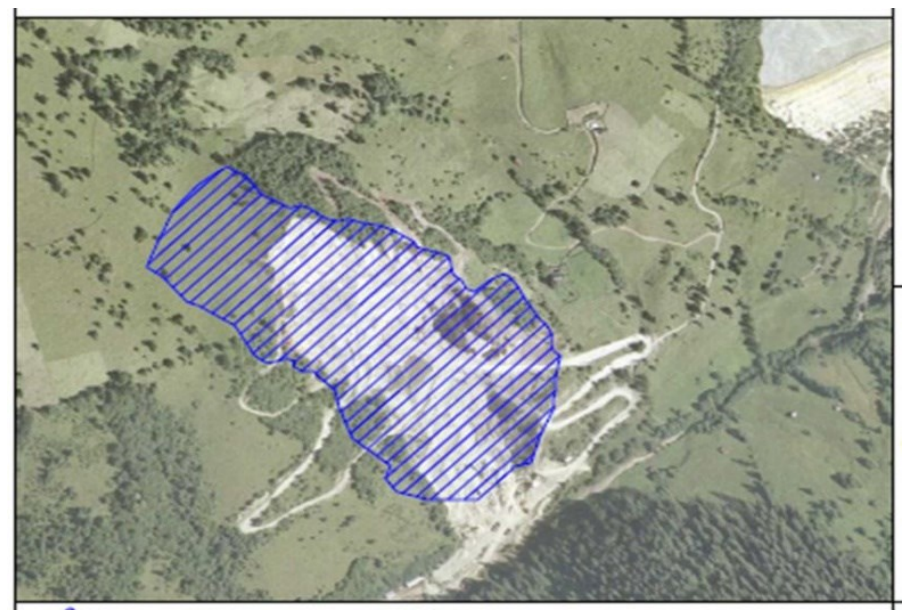

Fig. 5. Satellite image of the perimeter of "Pârâul Cailor" quarry.

The exploitation works are currently taking place at the level of 11 active stages. The exploitation method is applied in principle through 5 different technological variants.

\subsubsection{Protecting the rock deposit, land surface and buildings}

a) Safety pillars

The exploitation method and the technologies it applies do not create critical areas in the exploited perimeter of the rock deposit, requiring protection by safety pillars.

b) Managing the mining pressure and stability of the slopes 
Due to the programmed exploitation in the quarry, the geological reserves create imbalances, both in the plane of the panels and in the whole of the quarry, respectively between the forces demanding the slopes, the inner strength of the rock, under the direct action of the various external factors (especially technological ones) or internal (structural weakness, fissure, classical tendency), natural (environmental and tension factors such as the frozen-thawing repetitive effect) or human activities.

Given the fact that the exploitation method does not create areas with a breaking trend, the main elements of stability of the slopes and berms are constituted by the dimensional parameters of the steps, established according to the quarry monography:

- tread depth angle $=60-80^{\circ}$;

- quarry pit angle $=25-30^{\circ}$;

- the width of the berm without car transport min. $20 \mathrm{~m}$;

- the width of the berm with car transport min. $30 \mathrm{~m}$;

- the width of the safety berms min. 2-4 m;

- step height max. $20 \mathrm{~m}$.

\subsubsection{The consequences of event}

The event, produced on 10.05.2014, at the "Pârâul Cailor" quarry, had the following consequences:

- the sliding of material from the steps no. IV, V, VI, VII, VIII, on the vehicle loading platform, arranged in the III step;

- death of the I.F. driver and the damaging of the truck.

Much of the energy produced by the explosion is consumed to induce vibrations (seismic effect) in the mining massif.

Seismic effects or ground vibrations last longer than displacement, breakage, or projection and involve a much larger volume than offset matter.

The deposits in the Rarău mountains synclinal have been affected by major transverse faults that have produced dismantling and displacements of the order of hundreds of meters, which have generated secondary faults, supporting with much lesser effects than those of the major tectonic accidents.

\subsubsection{The main effects}

After geomorphological analyzes, tectonic accidents, fissures, cracks, correlation of the hourly data for the execution of the blasting works and the occurrence of the event, it is retained as a cause for the occurrence of the event, "spontaneous slipping of the rock bundles from the related fault area of the steps IV, V, VI, VII and VIII in the NE part of the central axis of the quarry front, due to the low cohesion of the hygroscopic material (clayey matrix), causing the rocks to move down from the above steps to the operating step III", where the loading platform of the material exploited material by the blasting works was organized.

Voluntary certification of blasting technology was needed to ensure seismically protection on basis of monitoring the seismic effect on blasting.

Revision of Work Security and Safety documentation to provide measures to avoid similar events.

\section{Conclusions}

Performing blasting operations generate a significant risk of harming the lives and health of people in the area. Failure to comply with the security instructions, to the extent that they 
impose strict obligations, for both execution personnel (trained blasters and other workers) and the coordinator of the work may lead to human casualties and / or damage or destruction of material goods or other unwanted technical events.

The two cases presented in the paper illustrate situations in which overlapping quarry security measures, insufficiently or incorrectly established and applied and their noncomplying by the trained staff in these activities have been overlapped.

Economic operators do not allocate sufficient resources to improve the security and health measures related to the blasting activities, in the sense that the specific working instructions are not updated when the conditions in the work front change the design of the blasting operation and the staff is not adequately trained and awared.

INCD-INSEMEX Petrosani can offer effective advice to improve the safety and health situation at work and to monitor the effects and blasting parameters.

The program of technical, scientific and research work in which INSEMEX is concerned and is currently involved, allows the transfer of useful information to economic agents and authorities to limit/prevent such situations that may result in human casualties or material damages.

\section{References}

1. Raport expertiză tehnică privind evenimentul produs, în data de 10.05.2014 la punctul de lucru Cariera „Pârâul Cailor” Pojorâta, INCD-INSEMEX, (2014).

2. Raport expertiză tehnică privind evenimentul produs, în data de 14.10.2011 la Cariera de piatră „DEALUL LUI TEFIC”' Isaccea, INCD-INSEMEX, (2014)

3. E.Gheorghiosu, Monitoringovy seizmickzy system INSEMEXU na lomoch INSEMEX implemented monitoring seismic system in Romania quarries, Blasting Techniques, Republica Slovacă, ISBN 978-80-970265-5-4, (2013)

4. D. Fodor, Explozivi industriali, Editura INFOMIN, Deva, (2000).

5. Dumitru, E., Bujor, A. - Seismologia exploziilor controlate din industrie, Editura Tehnică.

6. Tat, S., Zaporojan, M., Fissgus, K. - Explozivi şi tehnica împuşcării în industrie, Editura Tehnica, Bucureşti (1985).

7. Ciocoiu C., Gheorghiosu, E., Ghid de bună practică pentru depozitarea, transportul şi folosirea materiilor explozive, INSEMEX, (2008).

8. Calvin, J. K. - Surface blast design for Romanian operations.

9. ISEE - Performance Specifications For Blasting Seismographs, International Society of Explosives Engineers, 30325 Bainbridge Road Cleveland, OH 44139, Edition (2011).

10. Prof.S. Jazathu, Mr.Ch. Naveen, G.V. Rao, B.R.V, Susheel Kumar - Ground vibrations in opencast mine blast on structures vis-a-vis a local environmental effect and its mitigation through.

11. Paul W. Cooper, Explosives Enginnering, Wiley-VCH New York, Chichester, Weinheim, Brisbane, Singapore, Toronto.

12. J. Benterou, C.V. Bennett, G. Cole, D.E. Hare, C. May, E. Udd, (January 20, 2009), SPIE Defense, Security and Sensing Orlando, Fl, United States, (April 13, 2009) through (April 17, 2009).

13. Ass. Prof. Dr. Mostafa Tantawy Mohamed, Mining and Metallurgical Departament Faculty of Engineering Assist University Egypt.

14. D. Fodor - Ingineria Împuşcărilor, Materiale şi Tehnici de lucru (2), Editura Namaste Timişoara (2007), Editura Corvin - Deva (2007), Vol. 1. şi Vol. 2. 